\title{
Pathological study on some tissues of rat experimentally infected with Toxoplasma gondii
}

\author{
Entisar R. Alkennay \\ Department of Pathology \\ College of Veterinary Medicine \\ Mosul University
}

\author{
Shahla A. Hassan \\ Department of Biology \\ College of Education \\ Mosul University
}

$\begin{array}{cc}\text { Received } & \text { Accepted } \\ 22 / 03 / 2009 & 03 / 06 / 2009\end{array}$

\section{الخلإسة}

تضضمت هذه الدرلسة عزل المقوسة الكوندية من للسخد المجهضة للنع اجج ومتابع ـة

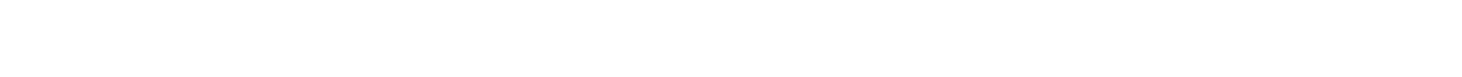
هقت تجريبياً بالمعلق الحاوي على الطفل.

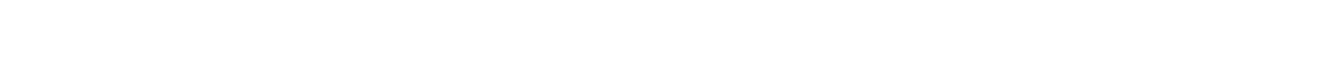

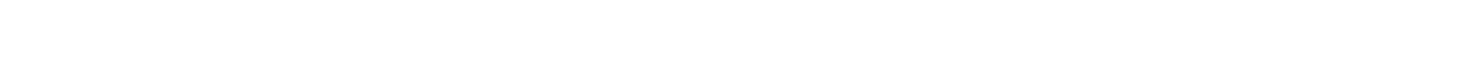

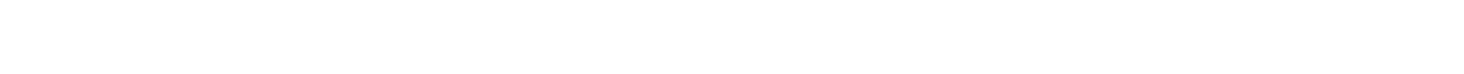

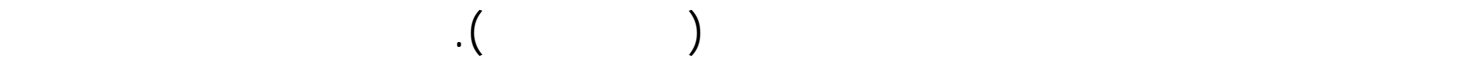

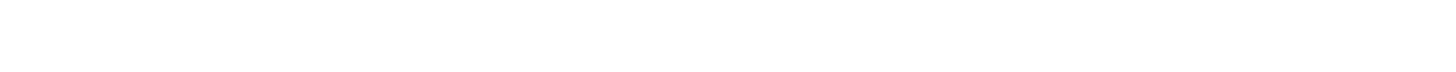
مع ارتشاح للخلايا اللففية مع التهلب للشبكية.

\section{ABSTRACT}

This study was conducted to isolate Toxoplasma gondii from aborted placentae of ewes, \& follow up the histopathological changes that produced in some different organs such as liver, brain \& eyes of rats which inoculated experimentally by suspension of the parasite.

Histopathological changes in brain represented by presence of tachyzoites \& tissue cyst at 30/45 days post infection associated with encephalomeningitis-while in liver, the lesions characterized by presence of perivascular \& periductular cuffing of tachyzoites associated with pyknotic nuclei of hepatocytes. Moreover, in the eye tachyzoites \& tissue cyst has been seen invaded in extraocular muscles, congestion of blood vessels with lymphocytic infiltration and retinochoroiditis, also has been seen. 


\section{INTRODUCTION}

Toxoplasmosis is a world wide infection in man and animals caused by obligate intracellular protozoan called Toxoplasma gondii ${ }^{(1)}$. Cats \& other felidae are considered the final host, while rodents, reptiles, birds and other mammals including human are intermediate host ${ }^{(2)}$.

The parasite causes sever economical loss implicating in reproductive failure in farm animals by foetal resorption mummification, still birth or abortion ${ }^{(3)}$. There are three infectious stages of $T$. gondii include tachyzoite, brachyzoite and sporozoite in oocyst ${ }^{(4)}$. The study of toxplasmosis is of medical importance due to socioeconomic impact of the disease in human suffering and the cost of care of sick childerns especially those with mental retardation and blindness are enormous. $T$ gondii its also of economic importance in veterinary public health since it is the major cause of animal abortions.

The aim of this study were to study the pathogenesis of Toxoplasma gondii isolated from placental ewes in rat experimentally. There has been no attempt to induce Toxoplasmosis in rat in Iraq, because that this study was conducted.

\section{Sampling}

\section{MATERIAL \& METHOD}

Three samples were collected from aborted placentae of ewes obtained from Mosul city. Touch imprint from placentae stained with Giemsa to seek for the presence of tissue cyst.

\section{Laberatory animal}

The experiment were carried out on 20 albino rat of both sex at age 4-5 weeks with weight ranged between $26-28 \mathrm{gm}$. Reared at animal house of in collage of the veterinary medicine of Mosul university. The rat given diet and water ad libidum after divided into two groups. Good circumstance including room temperature $\left(25-38^{\circ} \mathrm{c}\right)$ light $\&$ heat were maintained in animal houses.

\section{Isolation of T. gondii}

Isolation of $T$. gondii was carried out form palcentae of aborted ewes through the following steps. All samples were cut into small pieces then mixed with equal volume of normal saline \& grinded with mortar and pestle, the solution was filtered by using gauze to avoid large particles, then solution was placed into centrifuge $3000 \mathrm{pm}$ for 10 minutes, the supernatant discorded $\&$ the sediment was then suspended by normal saline, these process were repeated 3 times. Pencillines 1000 l.u and $100 \mathrm{mg}$ of streptomycin were added into the solution to prevent contamination ${ }^{(5)}$. 


\section{Inoculation of $T$. gondii in rat}

Drop of the suspension of aborted palcentae were placed on glass slide, fixed by methyl alcohol (95\%) stained with Giemsa $10 \%$ for an hour, examined by light microscope oil emersion power, then the number of the tissue cyst were calculated and 100 tissue cyst injected intraperitoneally (lp) in 10 rate of experimental group (G1) $)^{(6)}$.

\section{Histopathological study}

After 30 and 45 days, animal were scarified and liver, brain, eye tissues sample were fixed in $10 \%$ neutral buffered formalin and processed routinely for histology, tissues were cut at $5 \mu \mathrm{m}$ and stained with haematoxyline \& eosin $(\mathrm{H} \& \mathrm{E})^{(7)}$.

\section{Isolation of the parasite}

\section{RESULT}

Toch imprints of the aborted placentae stained with Giemsa, revealed presence of crescent shape tachyzoites and tissue cyst containing bradyzoites. Giemsa stained smears from brain \& liver tissues of experimentally intraperitoneal infected rats also revealed tachyzoites \& tissue cyst was similar to those seen in ewes.

\section{Gross pathological lesions}

No gross pathological change observed in infected group of rats.

\section{Histopathological lesions}

\section{Liver}

Histopathological sections of liver in $\mathrm{G}_{2}$ (infected) rats at 30 days post infection (PI) revealed dilation of central vein and cell swelling of hepatocytes. Some other sections showed pyknotic nuclei of hepatocyte associated with vacuolar degenerate perivasculer cuffing of tachyzoites, as well as vacuolar degeneration in epithelium lining bile duct and infiltration of mononuclear inflammatory cell lymphocytes (Fig, 1, 2) at 45 days PI similar changes that mentioned above seen in addition to congestion of blood vessels hypertrophy of kupffer cells, presence of tissue cyst and perivascular cuffing of tachyzoite (Fig. 3).

\section{Brain}

Histopathological change of brain tissue of rat infected with $T$. gondii 30 days, PI represented by congestion of cerebral blood vessels with evidence of perivasculer edema, gliosis associated with pyknosis of a strocytes and infiltration of mononuclear inflammatory cells (Fig. 4) while at 45 days PI the histopathological sections showed perivasculer cuffing of tachyzoite associated with presence of tissue cyst $\&$ invasion $\&$ 
proliferation of tachyzoite into endothelium lining intima of capillaries (Fig. 5). In maninges, histological section revealed mixed infiltration of mononuclear inflammatory cells and tachyzoit, as well as congestion blood vessels (all lesion mention above represented encephalomyelitis).

\section{Eye}

Histopathologically, eyes sections in rats infected with T. gondii at 30 days, revealed ketinitis which represented by presence of tachyzoit associated with infiltration of mononuclear inflammatory cells in retina, in addition to retinochoroiditis. At 45 day PI similar above lesion have been seen associate with choroiretensitis (Fig. 6, 7). Also some section showed invasion of tachyzoit in muscle fiber.

\section{DISCUSSION}

Toxoplasma gondii is regarded as one of the disease whose diagnosed depends on the histopathological change \& pathogenicity on the strain of parasite, host susceptibility $\&$ imune status ${ }^{(8)}$. This study was conducted to fined capability of $T$. gondii to produce histopathological changes in albino rats, revealed after 30 days PI crescent-shaped tachyzoit, this finding has been confirmed ${ }^{(9,10)}$. And ${ }^{(11)}$ who mentioned moderate resistance of the albino rats to the parasite.

In liver, histopathological finding in infected rat, detected presence of tachyzoite tissue cyst as well as hypertophy of kupffer cell and vacuolar degeneration, some section showed coagulative necrosis, and perivasculer cuffing of tachyzoite. This finding have been documented by other studies in mice ${ }^{(12,13)}$.

Defense mechanism in liver tissue take place by kupffer cells which appear hypertrophied in infected rats due to invasion of tachyzoites, these cells considered as phagocyte \& responsible for defense mechanism against antigen, then cells can secrete TNF- $\propto$ which in turn, produce cytokines in lymphocytes as a chemotactic factors, while perivasculer cuffing of tachyzoit occurs due to requirement of parasite to oxygen and nutrient material for developing stage ${ }^{(14,15)}$. In brain tissue of rat infected with $T$. gondii the presence of tachyzoite and tissue cysts juxtiposion to cerebral vessels, in cytoplasma of astrocytes and neurons as well as gliosis, resemble to that mentioned in mice which was documented by other studies ${ }^{(16)}$. Such feture may be explained by the fact that which requires large amounts of oxygen obtain from cerebral blood vessels. In addition the brain tissue is rich in lipids which required for parasite reproduction, beside the brain in lmmunopreviligid site, because it has CD4-CD-8 receptors to central nervous system in rats ${ }^{(17)}$.

The gliosis (proliferation of glial cells) in rats concomitant to infection by $T$. gondii as in mice described by ${ }^{(18)}$ then mentioned that 
invasion of parasite stimulate linkage of $\mathrm{T}$. cell with molecules on the surface of cerebral epithelium before extravasion \& the parasite is considered antigen the occurrence of gliosis is the evidence of stimulation of brain lmmune system against the parasite through releasing INF- $\propto$ and INF- $\gamma^{(18)}$.

In eye, the presence of tachyzoites and tissue cyst in different sit of eye tissue cause referitis, retinochoroiditis \& choroidretenitis resemble to that mentined in mice ${ }^{(19,20)}$.

In conclusion the current study disclosed that rat susceptible to $T$. gondii infection resembling to that occurs in mice through the appearance same histopathological lesions in liver, brain \& eye tissues that mentioned from other studies ${ }^{(22)}$.

\section{REFERENCES}

1) Kuantes, W. Toxoplasmosis. In: Oxford Textbook of medicine by weather all DJ $2^{\text {nd }}$ ed., Leding han, and warrell; 2004, 1: 506-509.

2) Lchhpunjania RL and Bhata R., Medical parasitology $-3^{\text {rd }}$ edit Jaypee Brothers New Delhi 2002, 113-119.

3) Buxton, D. Protozoan infections (Toxoplasma gondii, Neospora Caninum and sacocystis s.) in sheep and goats. Recent advance Vet Res. 1998, 29 : 289-310.

4) Dubey J. P. comparative infectivity of oocys and bradyzoites of Toxoplasma gondii for intermediate (mice) and definitive host (cat). Vet. Parasitology. 2006, 31 : 69-75.

5) Dubey J. P., Brake, RJ., and Murrell, K. D. Effect of the irradiation on the viability of Toxoplasma gondii cyst in tissues in mice and pig. Am. J. Vet. Res. 1986 ; 47: 267-299.

6) Liesenfeld, O. Oral infection of $\mathrm{C} 57 \mathrm{BL} / \mathrm{mice}$ with Toxoplasma gondii . A new model of inflammatory bowel disease. J. Infec. Dis., 2002, 185: 596-601.

7) Kim \& Weiss. The enzyme including creatin king, a denylate kinase and $\mathrm{C}$ to chronic the letter is important factor in infiating a poptosis.

8) Dubey JP. Toxoplasma, Hammondia, Besnoitia, sarcocystio and other tissue cyst forming coccidian of man and animals kreicrted. Parasite protozoa, $3^{\text {rd }}$. ed. Academic Press, Inc. New York.

9) Innes, E. A. Toxoplasmosis. Comparative species susceptibility and host immune response. Complmmunal Microbiol. Infect. Dis. 1997, 20: 131-138.

10) McGavenland Zachary, J. F. Centeral Nervous system; Toxoplamosis pathologic basic of vet. Disease. Mosby, Elsiever China., 2007, 4: 8, 895-896. 
11) Alkennany, E. R. and Alsaidya AA. Comparative pathological study on experimentally infection of Toxoplasma gondii oocysts isolated from infected cats after sporulation, Iraqi Journal of Vet. Sci. 2006, 20: 159-169.

12) Al-Hammoo RN. Pathological changes in mice and chickens embryo experimentally infected with $\mathrm{T}$. gondii isolated from placenta of women, Ewe and Goats. M.Sc. Thesis, University of Mosul (2005).

13) Jones, T. C., Hunt RD., and King, NW. Veterinary pathology. $6^{\text {th }}$ ed. Lippincott the Williams and Wilkins Company, New York, (1997).

14) Kwok, L. Y., Schluter, D.; Clayton, C. and Soldati, D. The antioxidant system in Toxoplasma gondii and the role of cystosolic catalase in defence against oxidative injury medical microbiology. 2004, 5:47-61.

15) Al-Kennany E. R. pathological study on the capability of Toxoplasma gondii to induce oxidative stress and initiation a primary lesion of Atherosclerosis experimentally in Broiler chickens. JAVA 2007; 8:938-942.

16) Dzbenski, T. H. Bitkowska, E., Golab, E. and Waloch M., Experimental toxoplasmosis of the central nervous system in rabbits as model of human infection 1998: $43: 162-166$.

17) Bhopale, GM. Pathogenesis of Toxoplasmosis Microbiol. Infect. Dis. 200326 : 213-322.

18) Wilson, E. H. and Hunter, C. A. The role of a strocytes in the lmmunopahtogensis of toxoplasmic encephalitis. Int. J. parasitol., 2004, 34 : 543-548.

19) Jubb, K. V. F, Kennedy P. C. and Palmer, N. Toxoplasmosis pathology of domestic animals 34d edition. A cadmic press Inc., America, 1993, $1: 489$.

20) Kanski, J. J. Uveitis Toxoplasmosic clinical ophthatmo logy $3^{\text {rd }}$ edit butler worth Heinmann, Great Britain 1997, 175-179.

21) Norsoe K., Marek, $M$ and Aso saif: Delevioration of visual function as examined by electro refinograms in Toxoplasma gondii infected IFN-r-Knochout mice. Investigative ophthalmology \& visual science 2005, 46 : 317-321. 


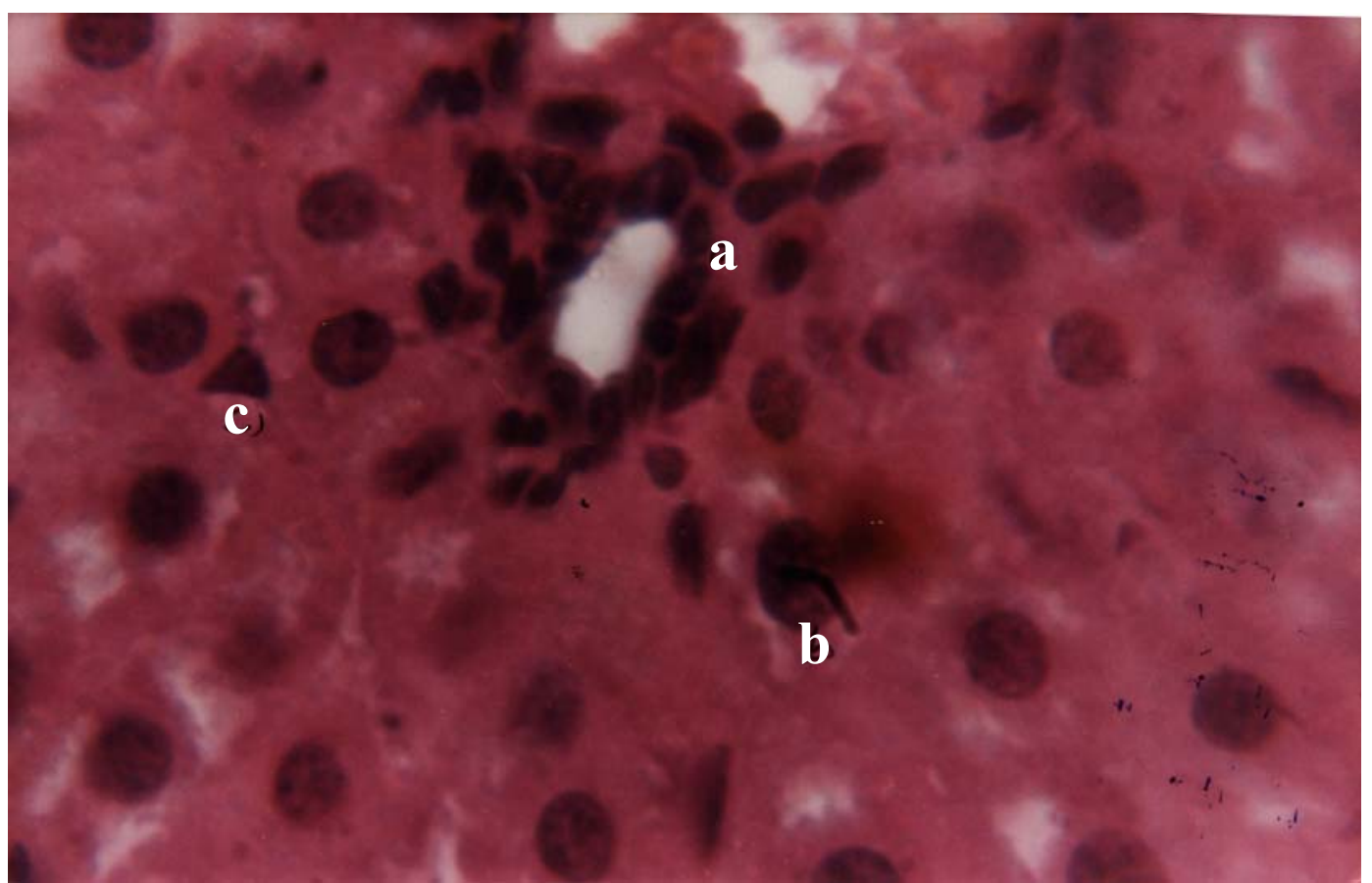

Fig. 1 : Photomicrograph of rats liver infected with $T$. gondii at 30 days showed, perivascular cuffing of tachyzoit (a), swelling of hepatocyte (b) and hypertrophy of kupffer cells (c) H \& E 400x.

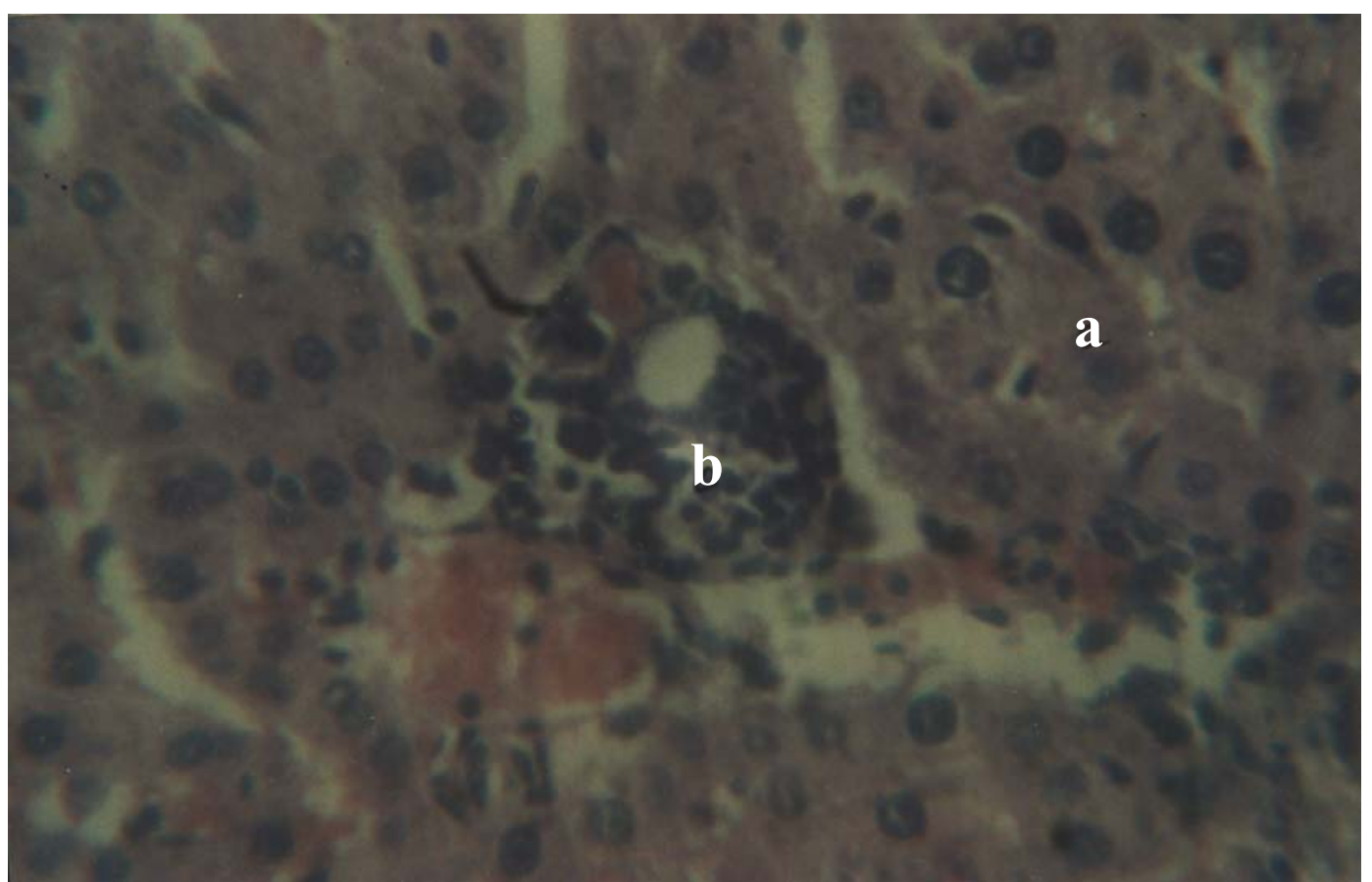

Fig. 2 : Photomicrograph of rats liver infected with T. gondii at 30 days showed, vacuolar degeneration of hepatocyte (a) mixed infiltration of tachyzoit and mononuclear inflammatory cells (b) H \& E 400x. 


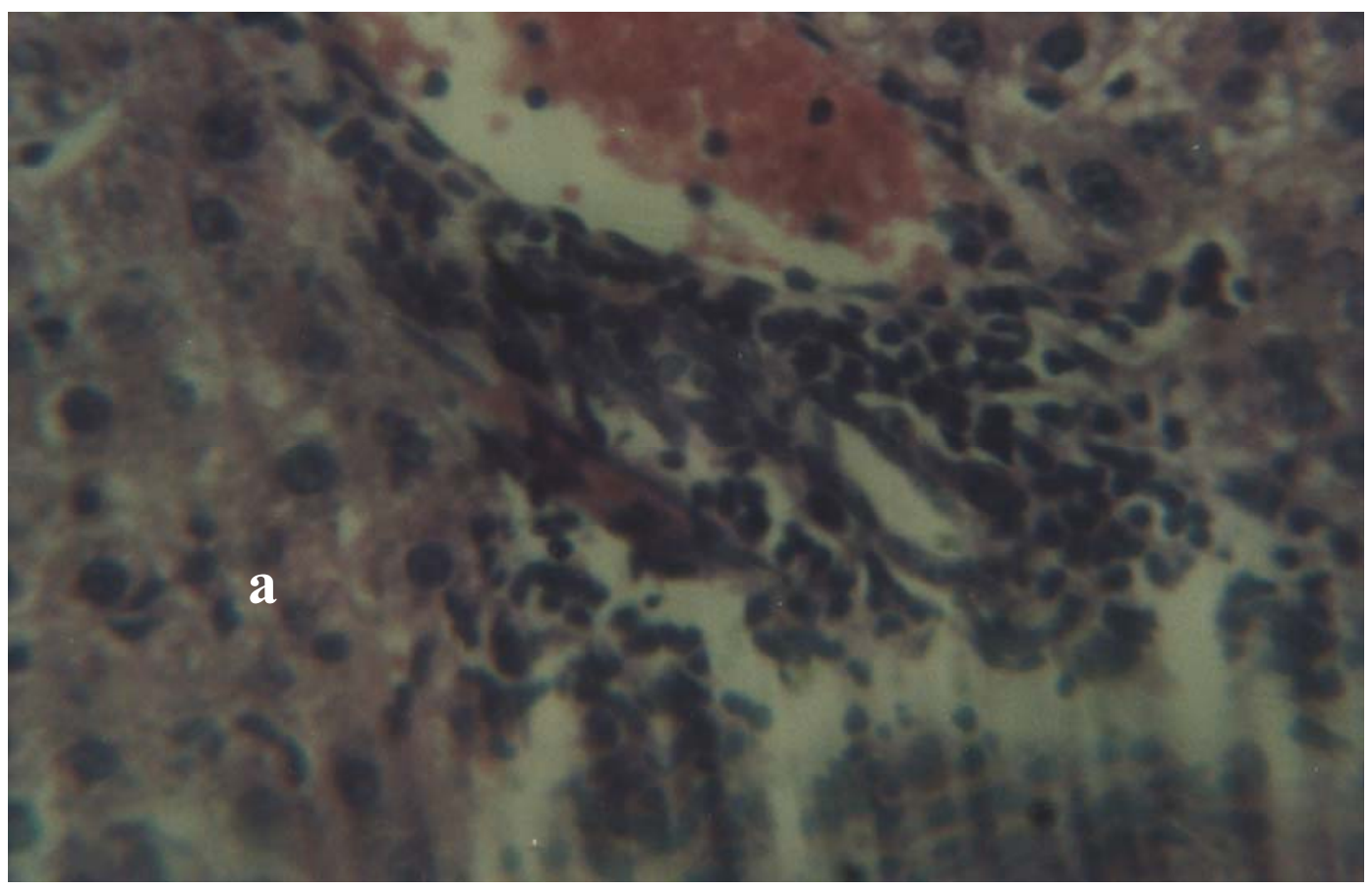

Fig. 3 : Photomicrograph of rats liver infected with T. gondii at 45 days showed, presence of tissue cyst and tachyzoit (a) hypertroephy of kupffer cells(b) H \& E 400x.

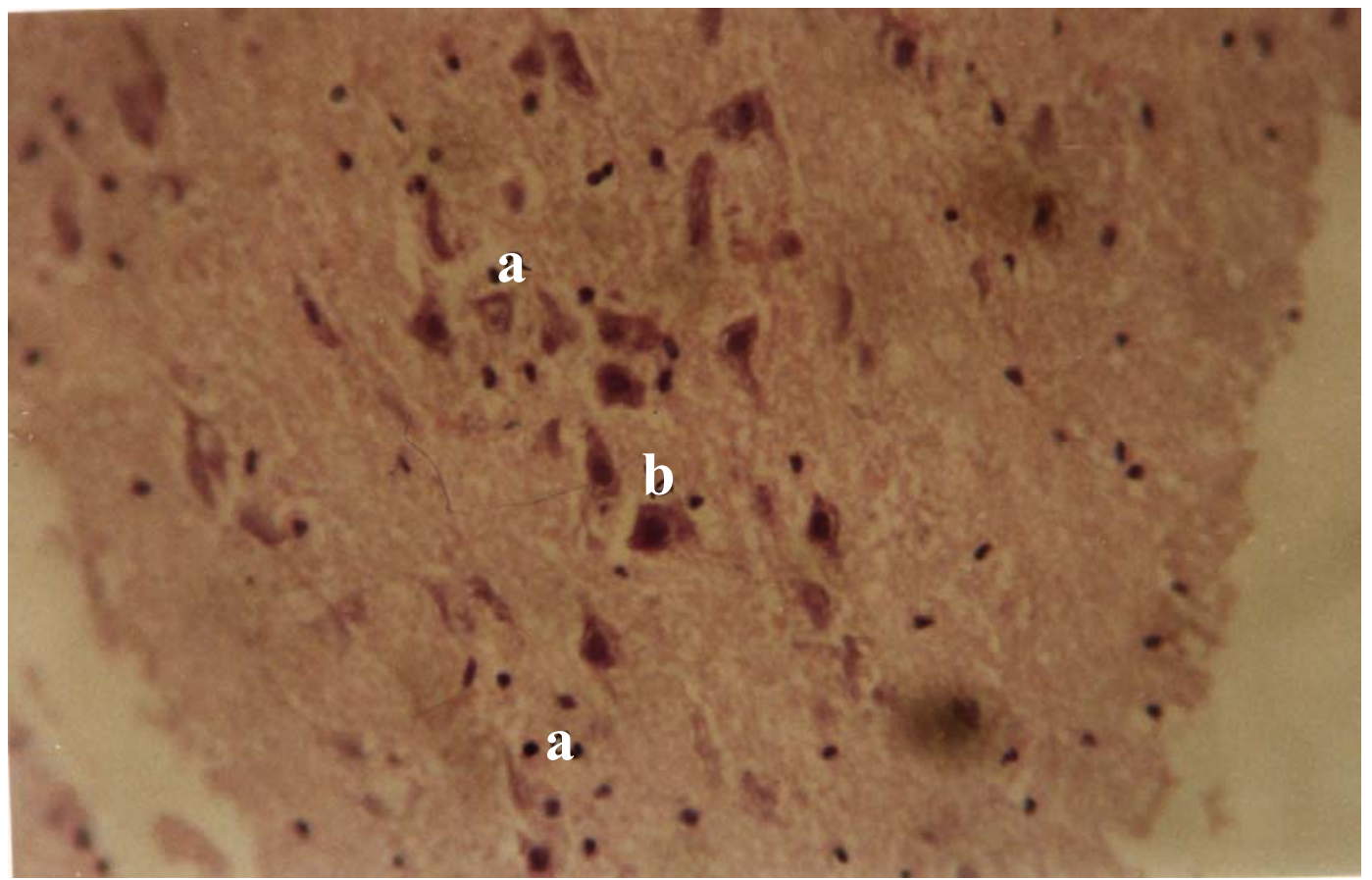

Fig. 4 : Photomicrograph of rats brain infected with T. gondii at 30 days PI showed, peri cellular edema(a), and degeneration of astrocyte(b) H \& E 400x. 


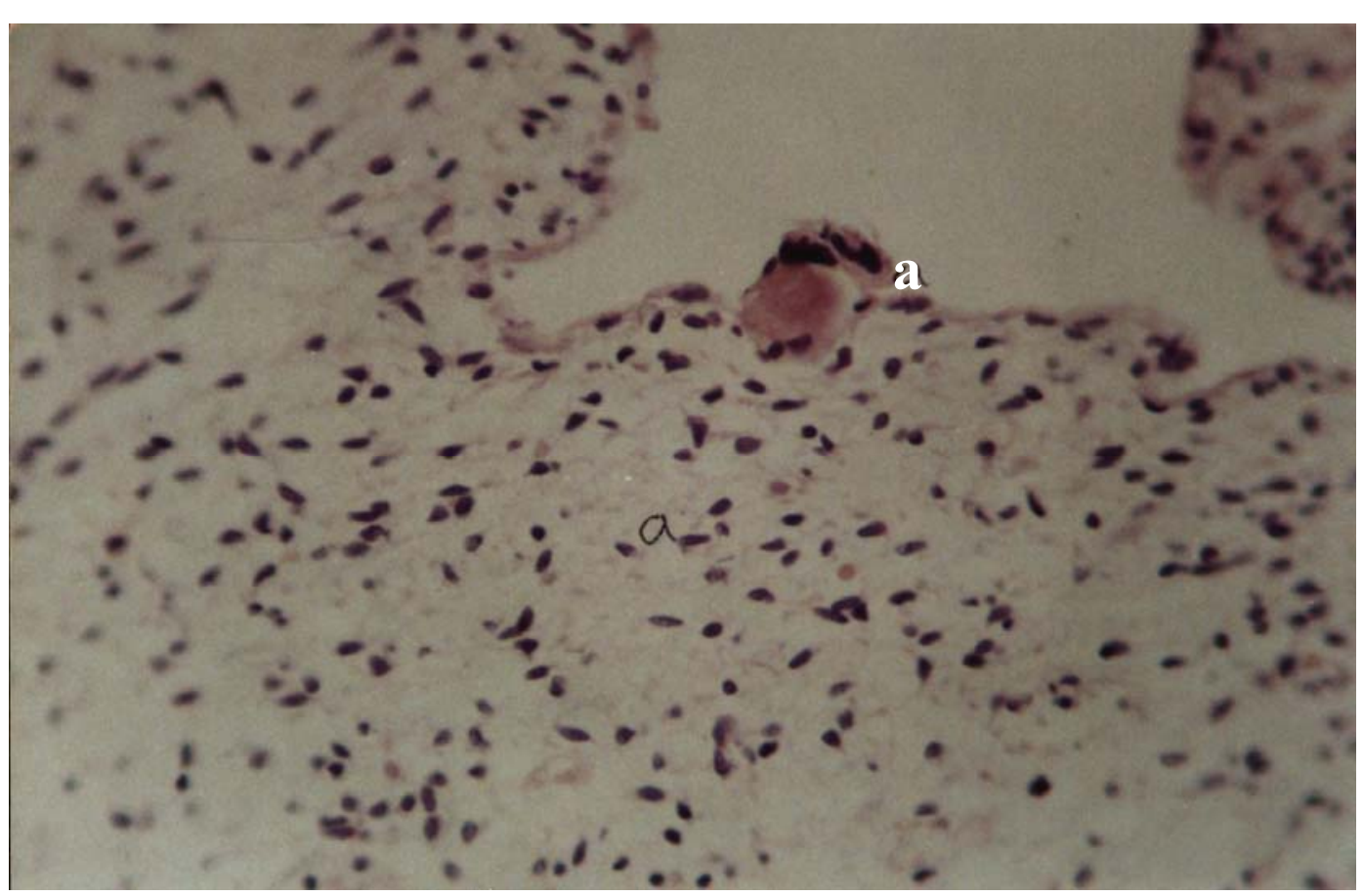

Fig. 5 : Photomicrograph of rats brain infected with $T$. gondii at 45 days PI showed, invasion and proliferation of tachyzoite into endothelium of cappellaries (a), H \& E 200x.

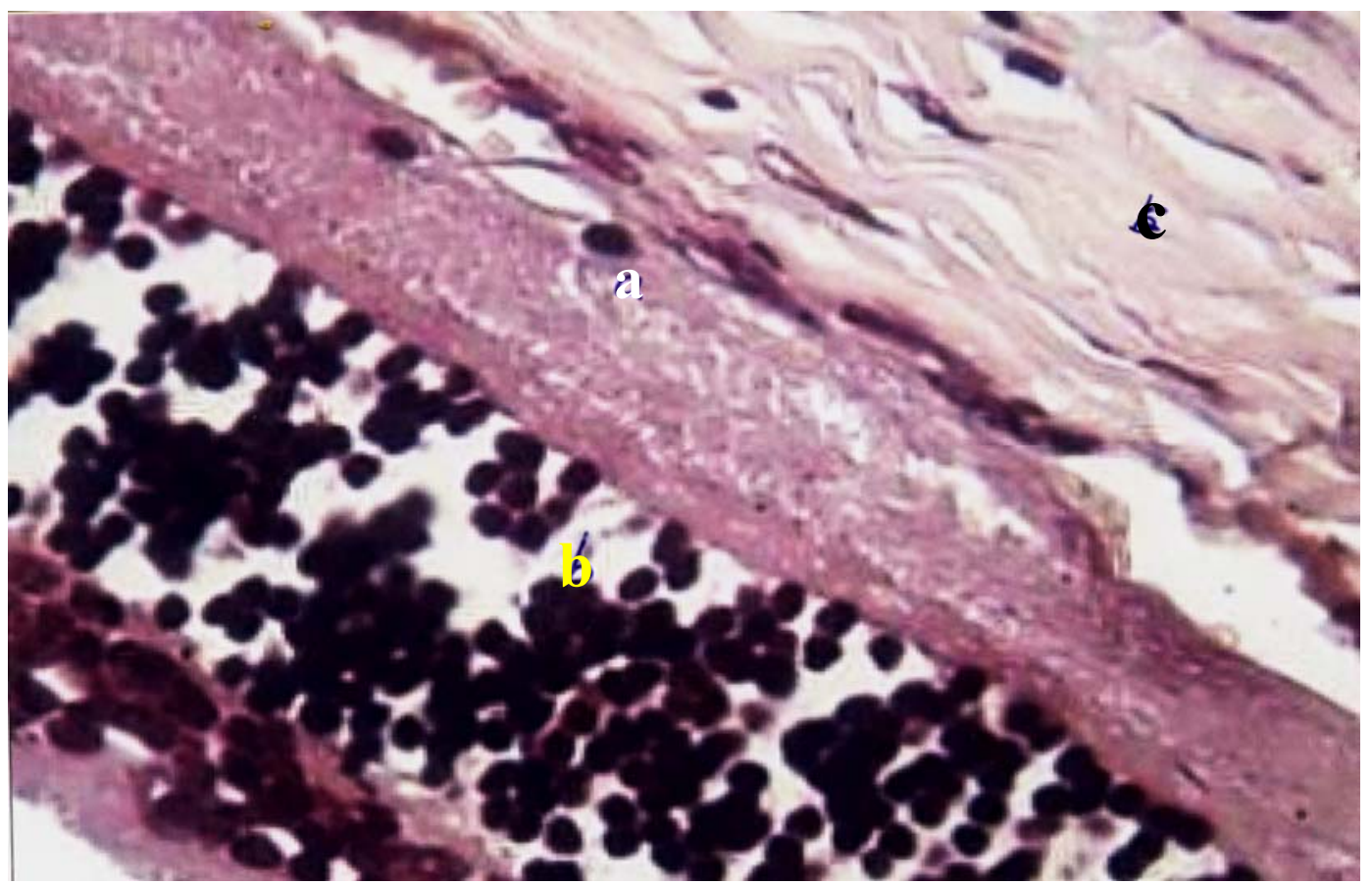

Fig. 6 : Photomicrograph of rats eye infected with T. gondii at 30 days PI showed, presence tachyzoite in the retina (a) associate with infiltration of mononuclear inflammatory cells(b) and hyalinization of muscle fibers (c), H \& E 400x. 


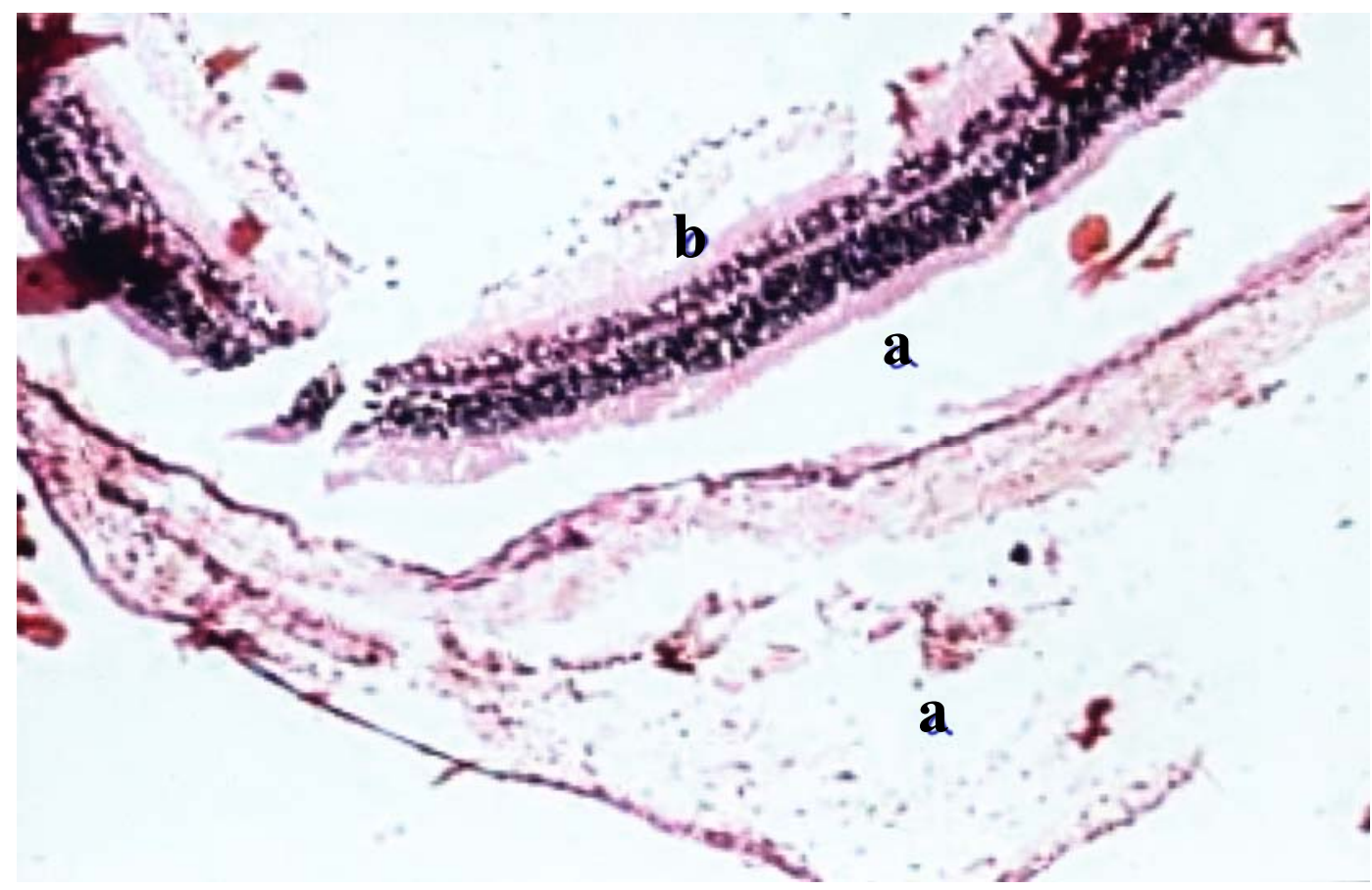

Fig. 7 : Photomicrograph of rats eye infected with T. gondii at 30 days PI showed, edema (a) choroiretenitis (b) H \& E 400x.

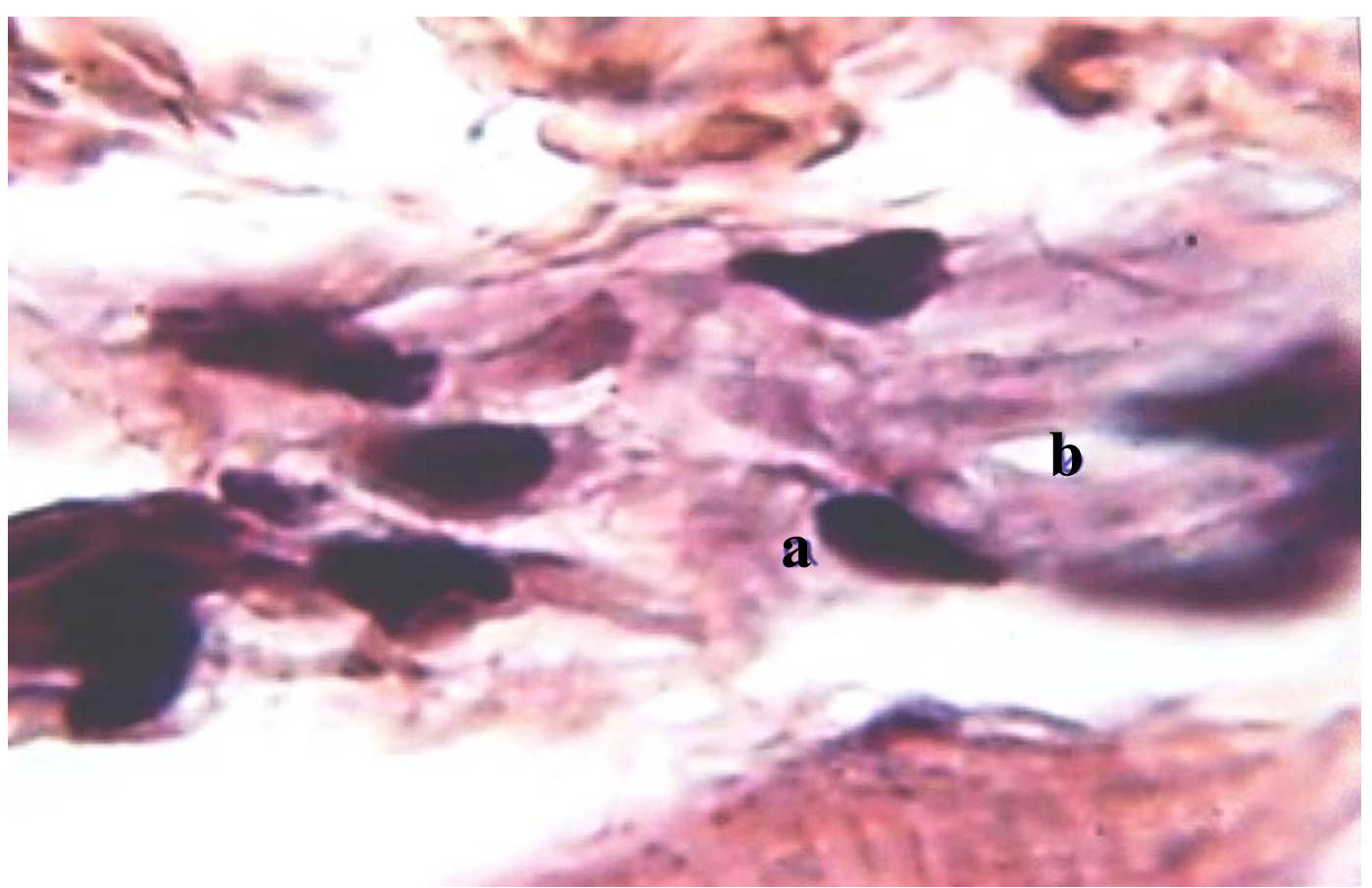

Fig. 8 : Photomicrograph of rats eye infected with $T$. gondii at 45 days showed presence of tacyzoite in ocular muscle(a) associated with edema(b), H\& E 1000x . 